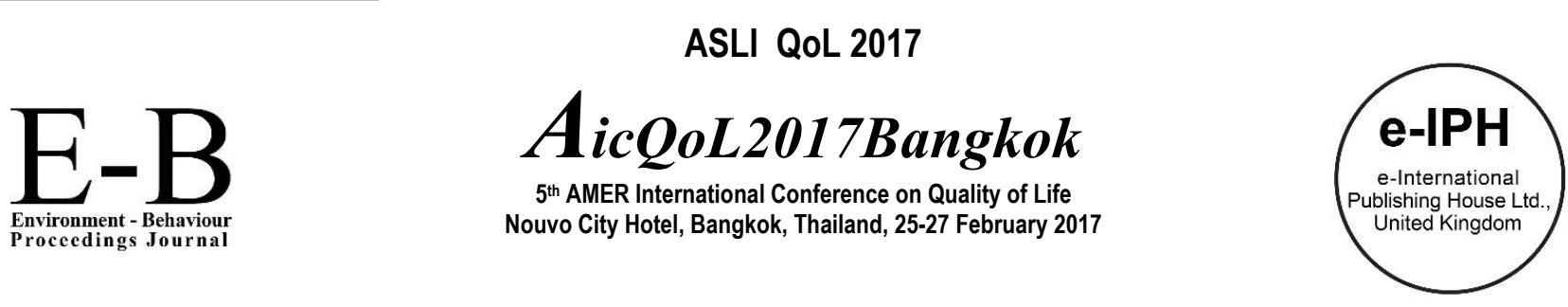

\title{
A Comparative Study on the Indoor Thermal Performance of New and Old Mosques
}

\author{
Noor Izzan Nordin*1, Alamah Misni2
}

\author{
${ }^{I}$ Faculty of Architecture, Planning and Surveying, Universiti Teknologi MARA, 40450 Shah Alam, Selangor Malaysia \\ ${ }^{2}$ Faculty of Architecture, Planning and Surveying, Universiti Teknologi MARA, 42300 Puncak Alam, Selangor Malaysia
}

\begin{abstract}
The study focus to compare the indoor thermal performance level between a new mosque and old mosques. Specific objectives are to identify the criteria that support sustainable practice, to analyse the indoor thermal performance using thermal monitoring tests and to propose strategic approaches for mosque design to achieve good indoor thermal performance towards sustainable practice. The data was carried out by experimental and observation. This data have been analyzed by Origin 6.0. Results show that the significant different between old and new mosque in indoor thermal performance. The main finding is influenced by the practice of passive design includes the building orientation and location, opening and building envelopes. Buildings should be correctly oriented to minimize solar gain and maximize natural ventilation. Keywords: Mosque; passive design; sustainable practice; thermal performance.

(C) 2017. The Authors. Published for AMER ABRA by e-International Publishing House, Ltd., UK. This is an open access article under the CC BYNC-ND license (http://creativecommons.org/licenses/by-nc-nd/4.0/). Peer-review under responsibility of AMER (Association of Malaysian Environment-Behaviour Researchers), ABRA (Association of Behavioural Researchers on Asians) and cE-Bs (Centre for Environment-Behaviour Studies), Faculty of Architecture, Planning \& Surveying, Universiti
\end{abstract} Teknologi MARA, Malaysia.

\subsection{Introduction}

Malaysia is being built towards a developed country with high rates of economic growth. Various types of buildings are erected such as residential, institutions, commercials, industrial, places of worship and others to meet the needs of the population. Mosque represents a place of multi-function and important institutes in Islamic societies because it is accommodating for daily spiritual, education and social activities. The green mosque emphasizes the major potential benefit includes environmental, social and economic. For environmental benefits green mosque can protect the ecosystem, improve the air qualities and conservation of natural resources. Lower operation and maintenance costs are one of the economic benefits of the green mosque. While the social potential benefits include improved health and comfort for consumers.

In Malaysia, there are two types of development which are the past/old and current development. The past/old building is called heritage building and the current building is a new building. Heritage building is precious national assets and should be preserved it especially on their design of art and architecture. Heritage building plays an integral part within the society to convey art and cultural that co-exits alongside the modern development. Heritage accentuated various ethnics and culture in Malaysia and mostly associated with the historical and elements of architectural. The new and old mosque building has own advantages and disadvantages in architecture and design and its influence on indoor thermal performance. This study focus is to compare the indoor thermal performance level between Kampung Raja Uda Mosque represents for a new mosque and Royal Mosque of Sultan Sulaiman for old mosques.

\footnotetext{
${ }^{*}$ Corresponding author1. Tel.: +6016-9802774

E-mail address: ziksya257@gmail.com
}

(C) 2017. The Authors. Published for AMER ABRA by e-International Publishing House, Ltd., UK. This is an open access article under the CC BYNC-ND license (http://creativecommons.org/licenses/by-nc-nd/4.0/). Peer-review under responsibility of AMER (Association of Malaysian Environment-Behaviour Researchers), ABRA (Association of Behavioural Researchers on Asians) and cE-Bs (Centre for Environment-Behaviour Studies), Faculty of Architecture, Planning \& Surveying, Universiti Teknologi MARA, Malaysia.

DOI: http://dx.doi.org/10.21834/e-bpj.v2i5.677 


\subsection{Literature Review}

Mosque definition by the Quran is the house of Allah, means the place reserved for the worship of Allah and it is glorified at all times (Hitam \& Talib, 2005). Mosque size depends on the locality need. The smallest size of mosque must be at least able to accommodate forty congregants for the Friday prayer and five daily prayers. According to Law (2000), heritage buildings are tangible manifestations of a physical expression and town's identity of the people of the town. The heritage buildings provided a link to the history background and culture of a particular town and nation. The heritage building is important to maintain the community identity, contribute to the quality of life for residents, enhance the image of the area and local neighborhoods, assist with economic development and tourism initiatives, and initiate conservation led regeneration.

Previous researcher, Bahobail and Al-Tassan, (2016) stated mosque design and architecture is facing a number of challenges due to the increase of the population and high demands on public services as well as infrastructure, especially in the city areas. However, a problem had been formed is a low quality indoor thermal performance. The construction of buildings that are not well organized and systematic will easily influence by discomfort in internal and external spaces through the current situation of global warming. Modern designs of a mosque rely more on a mechanical system to comfort the indoor space and as a result, it increases the annually energy consumption (Hameed, 2011). The demand for energy in mosques is critical, especially during the peak time of the day; Zuhur and Asar praying times.

The thermal performance of a building refers to the process of the heat transfer between a building and its surroundings. It calculates temperature variation inside the building over a specified time and helps one to estimate the duration of uncomfortable periods. It also involved heat exchange processes through opaque conduction such wall, roofs and doors, direct solar radiation penetrating through windows, and sensible and latent heat gain air exchange (Wong, 2004). However, in Soegijanto and Yohana, (2004) investigated that thermal condition inside the building was still within the comfort zone with slightly warm condition. They were measured air temperature, relative humidity and air velocity as well as by conducting simulation using Energy Plus software.

Designing a building that respond to the natural environment can provide a desired level of comfort in the prevailing environment (Baker, 1987). There are several criteria that support the sustainable design of heritage and modern mosque such as building orientation, natural ventilation, opening, building envelope, water element, and vegetation and so on. Rilling (2007) reported in a study, the positive impact on the consumption of electrical power because of changes in orientation and insulation appliances and also showed up to $43 \%$ lower cooling load. Natural ventilation is the process of supplying and removing air through an indoor space without use a fan or mechanical system. Natural ventilation also can increase the building thermal performance due an increase in natural air movement as a passive cooling strategy. Air flow caused by differences pressure between indoor and it's surrounding to provide ventilation and space cooling through controllable openings. It can control temperature particularly in hot and humid climate. Temperature control by natural ventilation is often the only means of providing cooling when mechanical air-conditioning is not used (Rofail, 2006). According to Klote (1991), this excellent upward and outward air pressure occurs as the air intake outside the building is as minimized as possible while the indoor space has a height as great as possible. Building envelope is the physical separator between the interior and exterior of a building (Cleveland, 2009). The different material components of building envelopes, such as foundation, walls, beams, connectors and roofing, can create paths for the transfer of thermal energy, which conduct heat in or out of the envelope (Hartweg, 2007).

Two types of parameters affecting thermal performance of a building are the unsteady climatic condition (i.e. temperature, wind speed and relative humidity) and design features (i.e. orientation, shading devices and building envelope) (Wong, 2004). The comfort zone is supposed to be between 20 and $27^{\circ} \mathrm{C}$ in temperature, and relative humidity (RH) between 20 and $80 \%$. The air velocity indoors that normally occur in a small room is about $0-0.5 \mathrm{~m} / \mathrm{s}$ (Givoni's, 1969).

\subsection{Methodology}

\subsection{Site study}

Data collection was carried out by experimental and observation focus on prayer hall for two of mosques in Selangor, Malaysia without use mechanical air-conditioning system. The mosques choosing were the Kampung Raja Uda Mosque represents for a new mosque and Royal Mosque of Sultan Sulaiman for old mosques. The figure 1 (a) and (b) are shown the measurement point for collecting data.

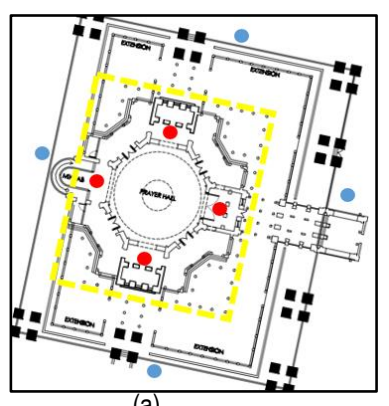

(a)

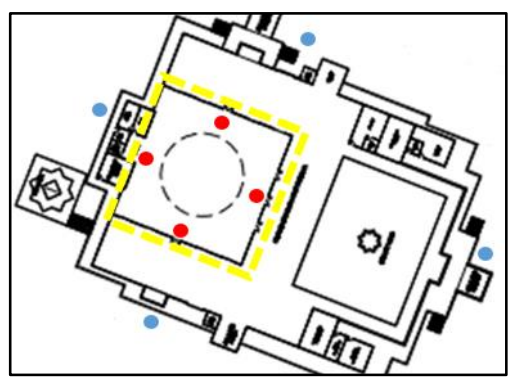

(b)
Legend of Measurement

O Outdoor ondoor

Prayer hall boundary

Fig. 1. (a) Royal Mosque of Sultan Suleiman, Klang; (b) Kg. Raja Uda Mosque, Port Klang. 


\subsection{Fieldwork period and analysis}

The experimental measure was practice by using thermal monitoring test (Tsi velocicals and anemometer) for collecting the indoor and outdoor weather data includes air temperature, wind speed, and relative humidity data compare to the metrology data from Malaysian Meteorology Department (September 2016). This research still allowed the outdoor data, because the outdoor usually influence directly to the indoor thermal performance. There are constraints that need to be considered in conducting the research such as raining, cloud and if have any haze in the study area. The data were collected as early as $08.00 \mathrm{am}$ till $19.30 \mathrm{pm}$ in with interval 00.30 hours on 25 and $29^{\text {th }}$ September 2016 adjacent to four azimuths in one meter above ground and one meter adjacent to wall. Data were analysed using Origin 6 software.

The observation method is using in this research and the purpose is partly explorative where the observation shall give the factors that's influenced to the indoor thermal performance of mosques. This is a crucial phase of the methodology because one of the major parts for collecting data is acquired here. All the data from observation is the key information in determining the strategic approach for mosque design to achieve good indoor thermal performance. The factors that's influence the indoor thermal performance for mosques divided to several parts. There are opening, orientation of the building, location of the building and the overall building envelope. Through observation, researcher can compare the data in term of their thermal performance between the old mosque and the new mosque. The data collection will be recorded in detail along with plan and photographs and will be summarized in the form of the report.

\subsection{Result and discussion}

\subsection{Weather}

In the study of old and new mosque was noticeable the several factors that influence to the indoor and outdoor temperature. There were divided to two factors included natural and man-made. The natural factor influence from wind speed and sun orientation. While the man-made factors such as opening, orientation of the building, location of the building, and the overall building envelope. Results have shown significant differences between old and new mosques in indoor thermal performance. The temperature differences of new mosques are lower on the average of $1.7^{\circ} \mathrm{C}$ at peak time of the day 15.00 hours was found in north direction. This old mosque in record the highest air temperature of $34.1^{\circ} \mathrm{C}$, compared with $32.4^{\circ} \mathrm{C}$ adjacent to all north side of new mosque, $\mathrm{Kg}$ Raja Uda Mosque at (15.00 hours) as shown at figure 2. Overall, $\mathrm{Kg}$. Raja Uda Mosque indoor temperature gradually increased during the morning until noon. The air temperature readings declined during the afternoon and into the evening. According to Olgyay (1963), Givoni (1969) and Montgomery (1987), the best temperature range for human comfort is $20-27^{\circ} \mathrm{C}$. From the metrology data, the cloud cover in this study area is about 7 okta.

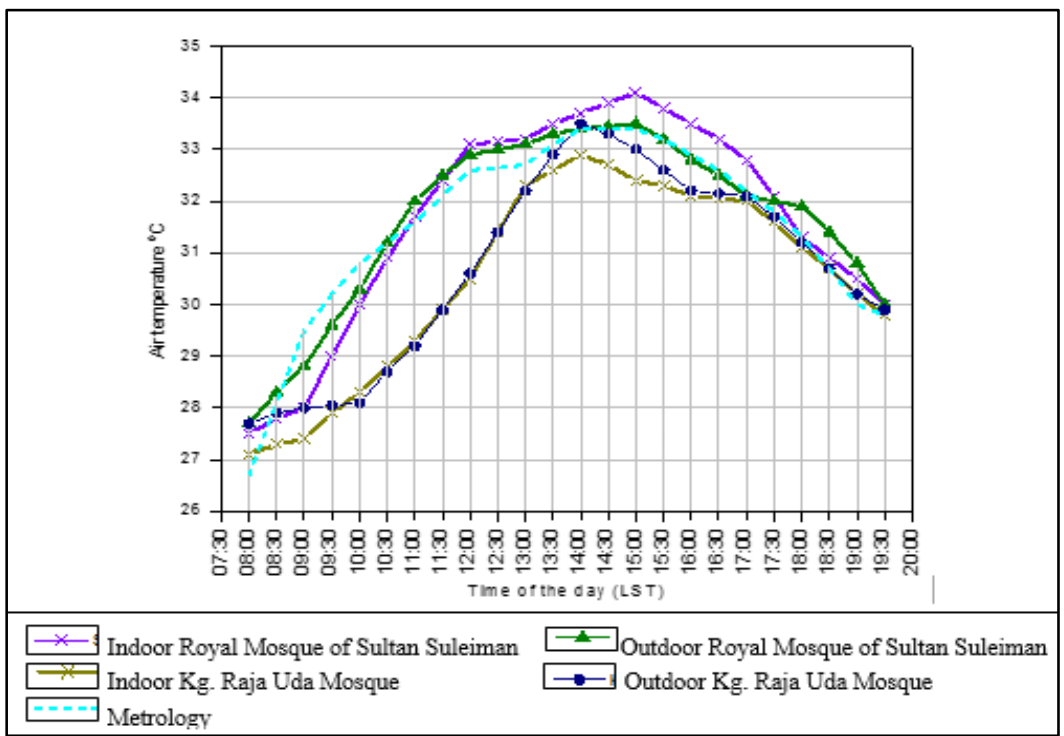

Fig. 2. Indoor and outdoor air temperature adjacent to the north wall of the Royal Mosque of Sultan Suleiman and Kg. Raja Uda Mosque

The RH levels for each of the study mosque were slightly different but still in the comfort zone range. Both of mosque in a range $51.2-79.2 \%$, adjacent to the north side wall. The RH difference of indoor for old mosques was lower on the average of $6.7 \%$ and the $\mathrm{RH}$ difference of outdoor old mosques was lower on the average of $8.6 \%$ during the peak time of the day at 15.00 hours. It was not really comfortable to the consumer. Givoni (1969) stated RH for comfort zone is $20-80 \%$. However, Abdullah (2007); MMD, (2010) stated Malaysia RH by the day it varies between 55 and $70 \%$. During the dry months, the mean daily minimum can be at the lowest at $42 \%$ and conversely reached the highest up to $70 \%$ during the wet months. According to Olgyay (1963), the wind is particularly important for comfort when temperatures are above $29^{\circ} \mathrm{C}$ and the relative humidity above $50 \%$. 


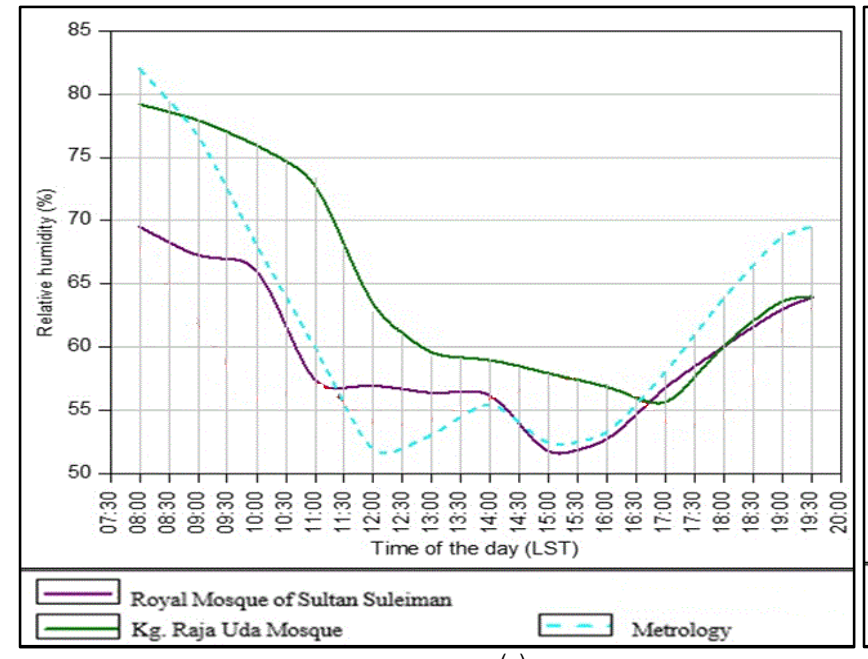

(a)

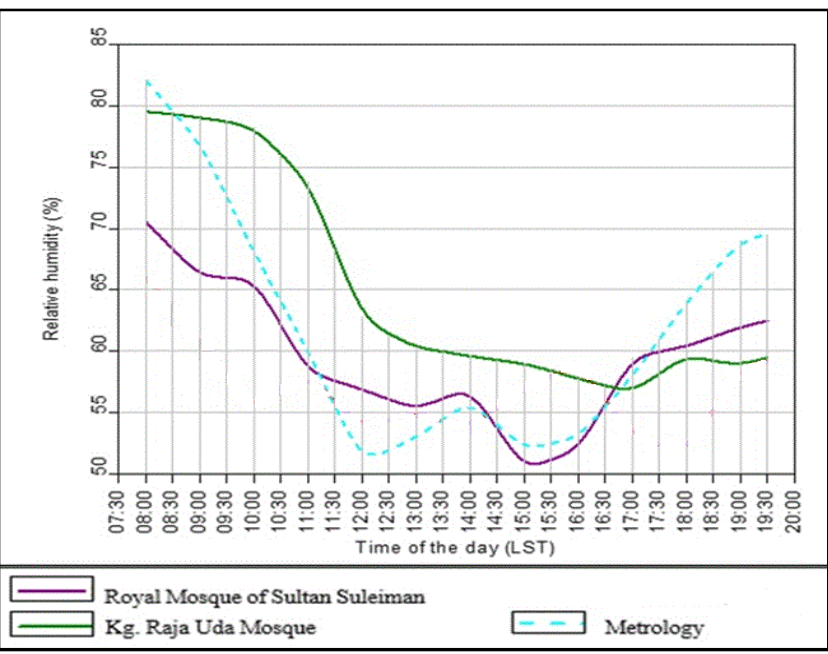

(b)

Fig. 3. (a) Indoor relative humidity adjacent to the north wall of the two mosques; (b) Outdoor relative humidity adjacent to the north wall of the two mosques

Both mosques of the study received a different pattern of wind speed. The result represents the indoor wind speeds of the new mosques shows it no wind speed for $\mathrm{Kg}$. Raja Uda Mosque (new mosque) in the morning till noon (12.30 hours). While the old mosque was slightly risen and reached a maximum of $9.5 \mathrm{~m} / \mathrm{s}$ in the evening (18.00 hours). From the result, it is clear that the outdoor wind speeds of the new mosques are fluctuated throughout the day. However, the Royal Mosque of Sultan Suleiman wind speed was lighter during the morning and slowly decreased till noon. But, it was increased late noon until evening above $9.2 \mathrm{~m} / \mathrm{s}$ at 18.00 hours.

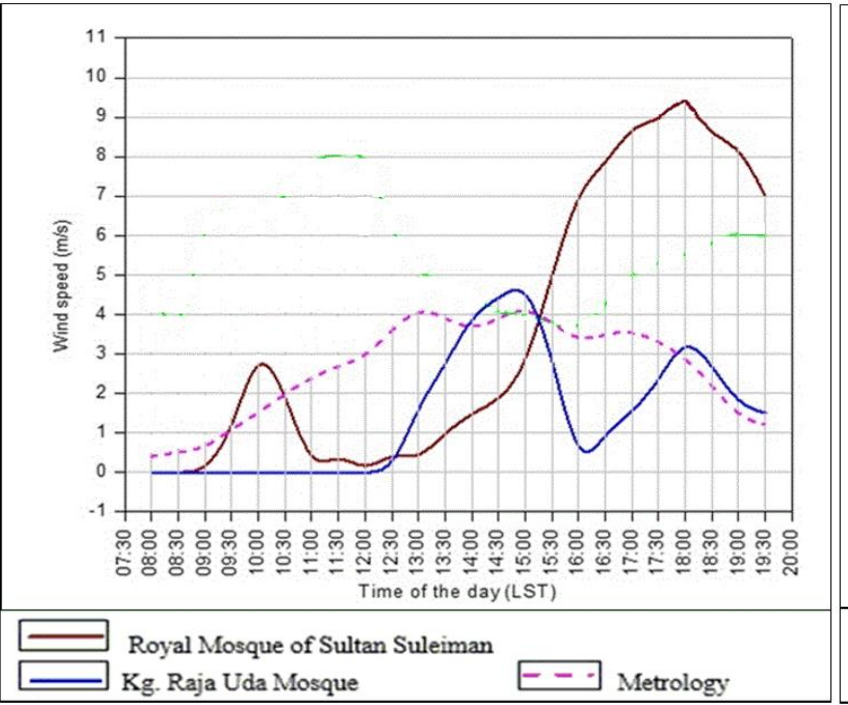

(a)

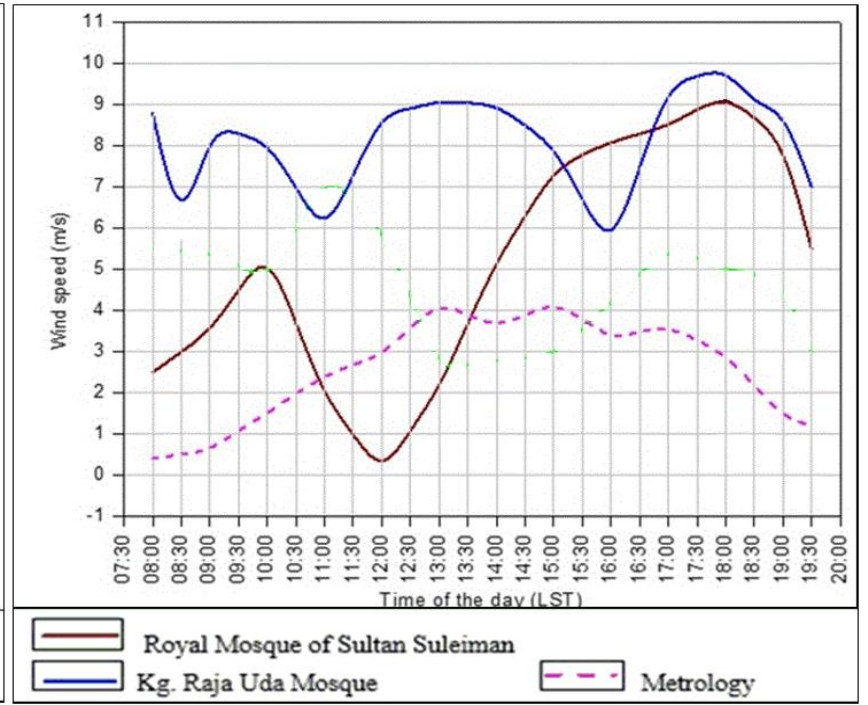

(b)

Fig. 4. (a) Indoor wind speed adjacent to the north wall of the two mosques; (b) Outdoor wind speed adjacent to the north wall of the two mosques

\subsection{Building construction}

\subsubsection{Construction type, material and ceiling height}

The results found that in the different categories of mosques with building construction and material.

Table 1. An average floor and roof surfaces

\begin{tabular}{lllll}
\hline Mosque Categories & \multicolumn{4}{l}{ Average building area $\left(\mathrm{m}^{2}\right)$} \\
\cline { 2 - 5 } & Ground floor & Upper floor & Total floor & Roof \\
\hline Old & 750 & 478 & 1228 & 2133 \\
New & 900 & - & 900 & 1908 \\
\hline All & 1650 & 478 & 2128 & 4041 \\
\hline
\end{tabular}

Table 1 shows that the different categories of mosque ground floor, upper floor and roof areas. There are smal gab between old and new mosque study areas. The mosque were built on reinforced concrete pad foundations, column and beam, and brick for the wall but with a different roof material. The new mosque roof used metal decking and old used concrete material with a dome. The roof and wall surfaces of the mosque were the biggest areas exposed to solar radiation, receiving and leading to storing of heat gain throughout 
the day. Table 2 shows that total areas for brick walls area were for both mosques. Almost similar the wall areas between old and new mosque. Ceiling heights were influenced to the indoor thermal performance both of the mosque, which old mosque $10 \mathrm{~m}$ and new one $9 \mathrm{~m}$, helping to maintain more comfortable temperatures at person height in the mosques.

\begin{tabular}{lll}
\multicolumn{3}{c}{ Table 2. Area of brick walls surfaces for the mosque } \\
\hline Azimuth & \multicolumn{3}{l}{ Mosque type @ wall $\left(\mathrm{m}^{2}\right)$} \\
\cline { 2 - 3 } & Heritage & New \\
\hline North & 232 & 189.9 \\
East & 234 & 207.6 \\
South & 228.7 & 189.9 \\
West & 215.6 & 236.7 \\
\hline Total & 910.3 & 824.1 \\
\hline
\end{tabular}

\subsubsection{Building orientation}

The orientation of the mosques was similar with each other in the direction of Qibla. The orientation of mosque was important to solve the solar gain and ventilation issues. Old mosque adjacent southeast side faced to the open area and north side faced to the new building. While the new mosque has two open area adjacent to southeast (courtyard) and northwest. Those directions meant the mosques were exposed to indirect solar radiation, which minimized heat gain. Shading is one of the ways to solve overheat indoor mosque space. Mostly the mosque had a balcony. The balcony provided shade and protect the glass surfaces from direct sunlight at the peak times of the day. Both of mosques have a huge shading device from the balcony roof. Because of that, the glass windows and doors received indirect solar gain to indoor space.

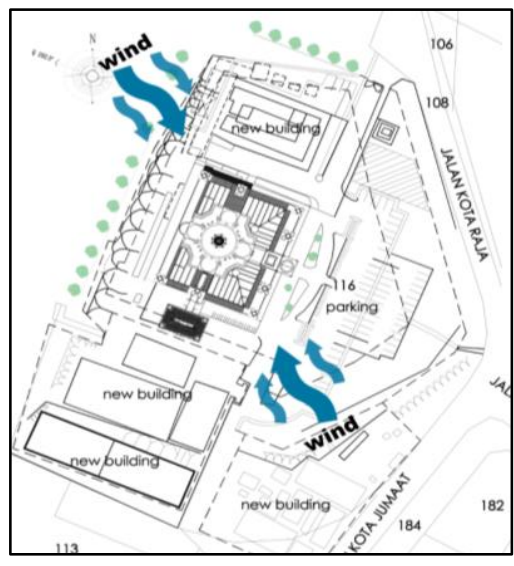

(a)

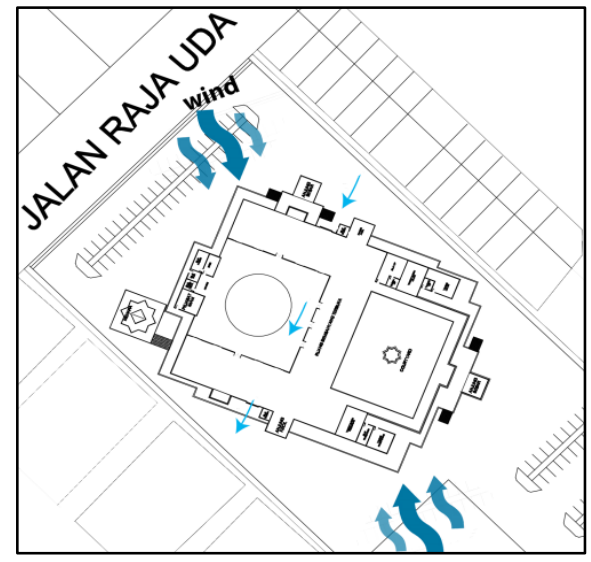

(b)

Fig. 5. (a) Wind flow at the Royal Mosque of Sultan Suleiman, Klang, Selangor; (b) Wind flow at the Kg.Raja Uda, Port Klang, Selangor

\subsubsection{Building envelope}

The main building envelopes were brick walls in this study area. The size of wall areas in all direction between were 824.1 to $910.3 \mathrm{~m}^{2}$, with an average of $867.2 \mathrm{~m}^{2}$. The old mosque had the almost similar envelope with a new mosque, with a total of $910.3 \mathrm{~m}^{2}$ of wall, $2133 \mathrm{~m}^{2}$ roof, and $750 \mathrm{~m}^{2}$ ground floor areas. The solar reflectance ratio of the surface of the walls and roof is very important. Both of mosques had a square layout for prayer hall. The color of the external envelope surfaces of a mosque has a tremendous effect on the impact of the sun on the building, and therefore on the indoor temperature. In this study, all the mosque buildings used light-colored paint for the walls and slightly different colors of roof covering. New mosque covered by metal roof with overlay layer of thermal insulation.

Table 3. Walls colour and roof material and colour for the mosque

\begin{tabular}{llll}
\hline Mosque Categories & Wall colour & $\begin{array}{l}\text { Roof } \\
\text { Color }\end{array}$ & Material \\
\hline Old & & Light grey + yellow dome & Concrete + stained glass \\
New & Light grey & Light grey + yellow dome & Metal roof + insulation \\
\hline
\end{tabular}

\subsubsection{Opening}

The openings are one of the criteria to achieve the comfort indoor thermal performance. The opening needed for cross ventilation and stack effect. There are several type of opening like wall opening, roof opening, floor opening and ornament at wall mosque. With the excellent design of cross air ventilation and stack effect may reduce the air temperature and RH level. According to Olgyay (1963), the highest heat gains entering the building are through glass windows via direct and diffused solar radiation. 

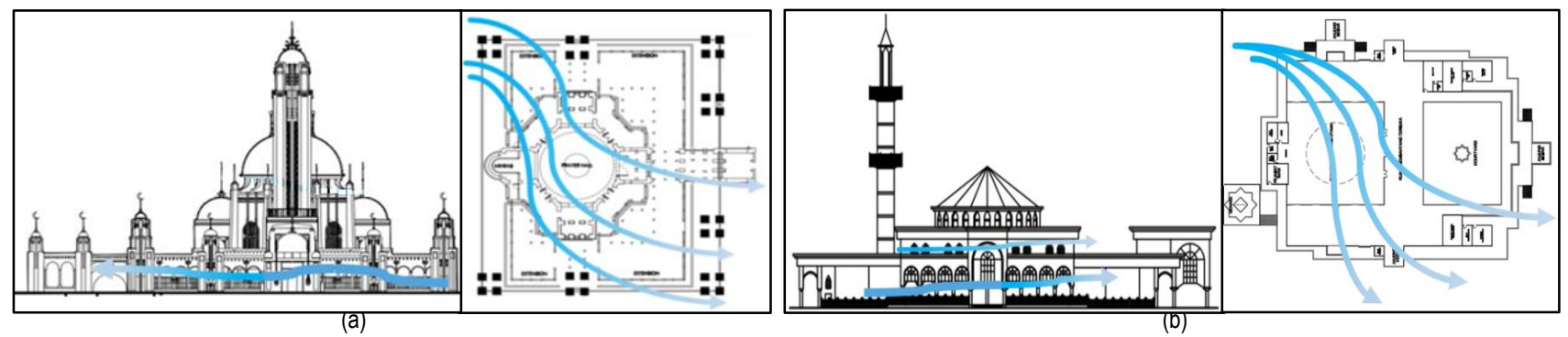

Fig. 6. (a) Cross ventilation and stack effect at the Royal Mosque of Sultan Suleiman, Klang, Selangor; (b) Wind flow Cross ventilation and stack effect at the Kg.Raja Uda, Port Klang, Selangor

Table 3 shows that total areas for the glazed area were for both mosques. Glazed window and door were found on all sides for the both of mosque. So that both of mosque have a practiced the cross ventilation. However, not all glazed was function as an opening. Certain glazed in heritage mosque just for natural lighting. The new mosque applied all the glazed as an opening. The maximum opening may have maximum natural ventilation. According to Moujalled, Cantin, Guarracino (2008), the openings allow an increase of indoor air speed. The stack effect occurs when the hot or warm air press to induce outward throughout roof opening. Klote (1991) stated this excellent upward and outward air pressure occurs as the air intake outside the building is as minimized as possible while the indoor space has a height as great as possible. Both of the mosques applied the cross ventilation and stack effect and is good for comfortable especially during peak hours.

Table 4. Area of glazed surfaces for the mosque

\begin{tabular}{lll}
\hline Azimuth & \multicolumn{2}{l}{ Mosque type @ glazed $\left(\mathrm{m}^{2}\right)$} \\
\cline { 2 - 3 } & Heritage & New \\
\hline North & 72.4 & 76.3 \\
East & 68.8 & 51.1 \\
South & 74.2 & 76.3 \\
West & 88.8 & 29.5 \\
\hline Total & 465.3 & 208.8 \\
\hline
\end{tabular}

\subsection{Conclusion}

A combination of climate and building variable may produce a great mosque in terms of environmentally-friendly and may help us to reduce global warming. In this study green mosque is focus on achieving a good indoor thermal performance in Selangor, Malaysia. The good indoor thermal performance of mosques may achieve by several of factors. They can be summarized as (i) weather data such as air temperature, wind speed, humidity and cloud cover; (ii) design variable includes optimized building orientation, building location, orientation and size of the opening, building material and construction; and building envelope. The best result for significance difference two categories of mosques is temperature, $1.7{ }^{\circ} \mathrm{C}, \mathrm{RH}, 8.6 \%$ and wind speed, new mosque fluctuated all the day, old mosque increase late noon. Proper design and planning of the building may minimize solar heat gain. The strategic approach includes best orientation and location of mosque; best orientation and maximum size of opening and suitable building envelopes and material.

\section{References}

Mizan Hitam \& Anuar Talib. (2005). The Malaysian Mosque: Evolution, Elements \& Meaning.

Law, C.L. (2000). Regenerating the city centre through leisure and tourism. Built Environment, 26(2),117-129.

Wong NH. (2004). Thermal performance of facade materials and design and the impacts on indoor and outdoor environment.

Soegijanto, F. X. N. S. \& Yohana, T. (2004). Study on Thermal Comfort in Istiqlal Mosque. The 5th International Seminar On Sustainable Environmental Architecture Bandung, Department of Engineering Physics ITB, Jl.

Baker, N. V. (1987). Passive and low energy building design for tropical island climates. Pall Mall, London: The Commonwealth Secretariat.

Dirk Rilling et al. (2007). Thermal simulation as design tool for residential buildings in Southeast Asia. Jurnal Alam Bina, 9 (3), 45-54

Rofail Tony. (2006). Natural Ventilation in Buildings. NEERG Seminar

Klote, J.H. (1991). A general routine for analysis of stack effect. National Institute of Standards and Technology, Report, United States Department of Commerce, Gaithersburg, pp: 28.

Cleveland, Cutler J., and Christopher G. Morris. (2009). Building envelopergy. Expanded Edition. Burlington: Elsevier.

Hartweg, L. (2007). The Passive Solar Exterior Envelope. Passive Solar Energy Info. Retrieved 28 September 2009, from http://www.passivesolarenergy.info/PassiveSolarExteriorEnvelope.htm/\#S2. 
Wong NH. (2004). Thermal performance of facade materials and design and the impacts on indoor and outdoor environment.

Givoni, B. (1969). Man, Climate and Architecture England Elsevier Publishing Company Ltd.

Olgyay, V. (1963). Design with Climate Bioclimatic Approach to Architectural Regionalism New Jersey Princeton University Press

Montgomery, D. A. (1987). Landscaping as a passive solar strategy Passive Solar journal, 4(1), 78-108.

(Abdullah, A. H. (2007). A Study on Thermal Environmental Performance in Atria in the Tropics with Special Reference to Malaysia. Unpublished PhD thesis. HeriotWatt University.)

MMD. (2010). General climate of Malaysia. Retrieved 13 July 2010, from http://www.met.gov.my/index.php?option=com_content\&task=view\&id=75 \&ltemid=1089

Olgyay, V. (1963). Design with Climate Bioclimatic Approach to Architectural Regionalism New Jersey Princeton University Press

Moujalled, B., Cantin, R., \& Guarracino, G. (2008). Comparison of thermal comfort algorithms in naturally ventilated office building. Energy and Buildings, 40, 22152223 